\title{
IMPLEMENTASI ALGORITMA FLOYD WARSHALL UNTUK MENENTUKAN LETAK DAN LOKASI PERUSAHAAN TRAVEL/RENTAL MOBIL DI KOTA BENGKULU
}

\author{
Yulia Darnita ${ }^{1}$, Rozali Toyib ${ }^{2}$, Rinaldi ${ }^{3}$ \\ ${ }^{1,2,3}$ Teknik Informatika, Fakultas Teknik, Universitas Muhammadiyah Bengkulu \\ Jl. Bali Po. Box, 118 Kota Bengkulu 38119 INDONESIA \\ ${ }^{1}$ yuliadarnita@gmail.com \\ ${ }^{2}$ rozalitoyib@gmail.com \\ ${ }^{3}$ rinaldi@yahoo.co.id
}

\begin{abstract}
Abstrak: Perusahaan rental mobil pastinya ingin menjadi istimewa dalam menyediakan jasa penyewaan mobil dan driver, penyedia layanan penyewaan kendaraan dengan cara sewa harian maupun kontrak bulanan dengan menggunakan sopir atau dengan menyetir sendiri. Para pendatang baru di kota Bengkulu banyak yang belum tahu dimana lokasi rental tersebut, dengan menggunakan aplikasi menggunakan Algoritma Floyd Warshall mengenai letak lokasi rental-rental tersebut sehingga para pendatang baru ataupun wisatawan bisa dengan mudah mencari rental mobil terdekat dengan lokasi mereka sekarang, Algoritma Floyd Warshall juga membandingkan semua kemungkinan lintasan pada graf untuk setiap sisi dari semua simpul dan Algoritma Floyd Warshall menerapkan pemrograman dinamis sehingga lebih menjamin keberhasilan penemuan solusi optimum untuk kasus penemuan lintasan terpendek (single pair shortest path), dengan memanfaatkan Android SDK dan sebuah GPS, LBS (Location Based Service) sesungguhnya adalah sebuah service untuk memberikan informasi sesuai lokasi kita berada. Informasi lokasi bisa dikembangkan pada smartphone berbasis sistem operasi Android, dari hasil pengujian untuk mencapai rute dengan jalur Terminal Panorama menuju Simpang Lima Suprapto, dengan jalur, maka pada jalur pertama dengan jarak $5 \mathrm{~km}$ dapat ditempuh dalam waktu 5,6 menit, jalur kedua dengan jarak 5,1 km dapat ditempuh dalam waktu 7,2 menit, jalur ketiga dengan jarak 5,5 km dapat ditempuh dalam waktu 7,4 menit dan jalur keempat dengan jarak 5,5 km dapat ditempuh dalam waktu 6,05 menit, maka Jalur terdekat yaitu jalur pertama yaitu terminal panorama Simpang Panorama - simpang padang harapan - tanah patah - simpang skip - simpang 5 dengan jarak $5 \mathrm{~km}$ dan waktu tempuh 5,6 menit.
\end{abstract}

Kata kunci : jalur terdekat, travel, rental, android

Abstract: Car rental companies certainly want to be special in providing car rental services and drivers, vehicle rental service providers by way of daily rental or monthly contract by using the driver or by driving alone. Newcomers in the city of Bengkulu do not know where the rental location is, using the application using Floyd Warshall Algorithm on the location of these rentals so that newcomers or tourists can easily find the nearest car rental to their current location, Floyd Warshall Algorithm also compares all possible paths on the graph for each side of all vertices and Floyd Warshall's algorithm applies dynamic programming so as to ensure the successful discovery of the optimum solution for the case of the discovery of the shortest path. By utilizing the Android SDK and a
GPS, LBS Location Based Service) is actually a service to provide information according to the location we are. location information can be developed on Android-based smartphone operating system, from the test results to reach the route with the Panorama Terminal to Simpang Lima Suprapto, with the line, then on the first line with a distance of $5 \mathrm{~km}$ can be placed within 5.6 minutes, the second line with a distance $5.1 \mathrm{~km}$ can be reached in 7.2 minutes, the third line with a distance of $5.5 \mathrm{~km}$ can be reached in 7.4 minutes and the fourth line with a distance of $5.5 \mathrm{~km}$ can be placed within 6.05 minutes, the closest line namely the first line of the Panorama Terminal - intersection panorama - intersection of hope - broken ground - 
Jurnal Pseudocode, Volume IV Nomor 2, September 2017, ISSN 2355-5920 www.ejournal.unib.ac.id/index.php/pseudocode

intersection skip - intersection 5 witha distance of5 $\mathbf{~ k m}$ and travel time of 5.6 minutes.

Keywords: nearest lane, travel, rental, android

\section{PENDAHULUAN}

Kemajuan teknologi tidak dapat dipungkiri teknologi masa kini berkembang sangat pesat, hal ini dapat dibuktikan dengan banyaknya inovasiinovasi yang telah dibuat di dunia ini dari yang sederhana hingga yang menghebohkan dunia. Kemajuan teknologi memang sangat penting untuk kehidupan manusia zaman sekarang karna teknologi salah satu penunjang kemajuan manusia, Di banyak belahan masyarakat teknologi telah membantu memperbaiki ekonomi, pangan, transportasi dan masih banyak lagi. Alat transportasi yang disediakan menjadi lebih modern dan mudah digunakan oleh berbagai pihak. Dengan adanya alat transportasi maka masyarakat Indonesia akan lebih mudah dalam melakukan perjalanan. Industri smartphone, ponsel dengan sistem operasi android menjadi yang terpopuler saat ini. Tentunya banyak penggemar android yang menantikan akan seperti apa perkembangan android tersebut di masa depan.

Perusahaan rental mobil pastinya ingin menjadi istimewa dalam menyediakan jasa penyewaan mobil dan driver, penyedia layanan penyewaan kendaraan dengan cara sewa harian maupun kontrak bulanan dengan menggunakan sopir atau dengan menyetir sendiri. Pemanfaatan rental mobil ini dapat dikembangkan sebagai terobosan bagi masyarakat atau perusahaan yang tidak memiliki alat transportasi yg akan digunakan untuk operasional, efektif bagi perusahaan karena tidak perlu mengeluarkan biaya tambahan untuk biaya pemeliharaan alat transportasi, sebab dengan menyewa kendaraan operasional, perusahaan tidak perlu mengeluarkan biaya tambahan untuk pemeliharaan alat transportasi. Permasalahan yang terjadi terkadang si penyewa bingung mencari dimana lokasi perusahaan rental car terdekat. Salah satu cara untuk mengatasi masalah ini yakni dengan menggunakan smartphone dengan sistem operasi android serta pengimplementasian Algoritma Floyd Warshall sebagai salah satu metode solusi tercepat untuk sampai ke tempat tujuan.

Algoritma Floyd Warshall merupakan salah satu varian dari pemrograman dinamis, yaitu suatu mode yang melakukan pemecahan masalah dengan memandang solusi yang akan diperoleh sebagai suatu keputusan yang saling terkait dan digunakan secara luas pada metode pencarian jalur dan grafik, yakni sebuah proses penentuan letak dan lokasi dengan penambahan fungsi heuristic untuk mencapai kinerja yang lebih baik.

Global Positioning System atau yang biasa disingkat GPS. GPS bisa berupa piranti tambahan atau bisa juga piranti terintegrasi pada smartphone. Dengan memanfaatkan Android SDK dan sebuah GPS, LBS (Location Based Service) sesungguhnya adalah sebuah service untuk memberikan informasi sesuai lokasi kita berada. Informasi lokasi bisa dikembangkan pada smartphone berbasis sistemo perasi Android.

\section{LANDASAN TEORI}

\section{A. Peta Digital}

Peta merupakan nyajian grafis dari permukaan bumi dalam skala terrtentu dan digambarkan pada bidang datar melalui bidang datar melalui sistem proyeksi peta menggunakan simbol-simbol tertentu sebagai perwakilan dari objek-objek spasial dipermukaan bumi [1]. Sebuah peta harus memiliki syarat-syarat sebagai berikut:

1. Peta tidak boleh membingungkan. Dalam hal ini peta perlu dilengkapi: 

a) Keterangan atau legenda
b) Skala peta
c) Judul peta
d) Bagian dunia mana

2. Peta harus dengan mudah dapat dimengerti atau ditangkap maknanyaoleh si pemakai peta. Supaya mudah dimengerti atau ditangkap maknanya, digunakan:
a) Tata warna
b) Simbol
c) Sistem proyeksi atau sistem koordinat

3. Peta harus memberikan gambaran yang sebenarnya. Ini berarti peta itu harus cukup teliti sesui dengan tujuannya.

Klasifikasi peta dapat dibedakan dan ditinjau dari 4 segi:

a. Macam peta ditinjau dari segi jenis

1. Peta Foto, peta yang dihasilkan darimosaik foto udara/foto yang dilengkapi garis kontur, nama dan legenda.

2. Peta Garis, peta yang meyajikan detil alam dan buatan manusia dalam bentuk titik, garis dan luasan.

b. Macam peta ditinjau dari skala

1. Peta skala besar, yaitu peta dengan skala (1:50.000) atau lebih besar (1:25.000).

2. Peta skala kecil, yaitu peta dengan skala1:500.000 atau lebi kecil.

c. Macam peta ditinjau dari fungsinya

1. Peta umum, merupakan peta yang berisi penampakan-penampakan umum.

2. Peta tematik, merupakan peta yang menunjukkan hubungan ruang dalam bentuk atribut tunggal atau hubungan atribut.

3. Kart, merupakan peta yang didesain untuk keperluan navigasi, nautical, dan aeronautical.

d. Macam peta yang ditinjau dari macam persoalan (maksud dan tujuan), ada banyak sekali macamnya. Misalnya: peta kadaster, peta geologi, peta tanah, peta ekonomi, peta kependudukan, peta tata guna tanah, dan sebagainya.

\section{B. Global Positioning System (GPS)}

GPS atau Global Positioning System, merupakan sebuah alat atau sistem yang dapat digunakan untuk menginformasikan penggunanya dimana lokasinya berada (secara global) di permukaan bumi yang berbasiskan satelit. Data dikirim dari satelit berupa sinyal radio dengan data digital. Dimanapun pengguna tersebut berada, maka GPS bisa membantu menunjukan arah. Layanan GPS ini tersedia gratis. Awalnya GPS hanya digunakan hanya untuk kepentingan militer, tapi pada tahun 1980-an dapat digunakan untuk kepentingan sipil. GPS dapat digunakan dimanapun juga dalam 24 jam. Posisi unit GPS akan ditentukan berdasarkan titik-titik koordinat latitude dan longitude[2].

\section{Location Based Service (LBS)}

Location Base Services (LBS) adalah aplikasiyang bergantung pada pada lokasi tertentu dan didefinisikan pula sebagai layanan informasi dengan memanfaatkan teknologi untuk mengetahui posisi sesuatu. Layanan berbasis lokasi (LBS) menggunakan teknologi Positioning System, teknologi ini memungkinkanpara pengguna dapat memperoleh informasi lokasi sesuai dengan kebutuhannya.

Location Base Services (LBS) termasuk dalam kategori teknologi yang sama dengan geographic information system (GIS), dan aplikasi global positioning system (GPS), yaitu dikenal dengan teknologi geospatial. Teknologi ini terdiri atas perangkat untuk mengumpulkan, menyimpan, menganalisa dan mendistribusikan data yang sesuai 
Jurnal Pseudocode, Volume IV Nomor 2, September 2017, ISSN 2355-5920 www.ejournal.unib.ac.id/index.php/pseudocode

dengan kebutuhan pengguna terhadap sistem koordinat bumi. Layanan ini menjadi sangat penting bagi penggunanya karena mampu menghubungkan antara lokasi geographic informasi terhadap lokasi penggunanya, hal ini sangat mendukung era mobilitas seperti pada masa ini. Keberadaan aplikasi Location Base Services (LBS) merupakan hasil penggabungan dari tiga buah teknologi yaitu New Information and Communication Technologies (NICTS), internet, dan Geographic Information System (GIS) dengan menggunakan database spasial.

Teknologi Location Base Services (LBS) ini terdiri atas perangkat-perangkat yang yang digunakan untuk mengumpulkan, menyimpan, menganalisa dan mendistribusikan data dan informasi pada berdasarkan sistem koordinat geographic bumi secara realtime. Identifikasi kordinat pengguna memungkinkan aplikasi Location Base Services (LBS) untuk menyediakan layanan bagi penggunaperangkat mobile[3].

\section{Algoritma Floyd Warshall}

Algoritma Floyd Warshall adalah salah satu algoritma dari pemrograman dinamis, yaitu suatu metode yang melakukan pemecahan masalah dengan memandang solusi yang akan diperoleh sebagai suatu keputusan yang saling terkait. Artinya solusi- solusi tersebut dibentuk dari solusi yang berasal dari tahap sebelumnya dan ada kemungkinan lebih dari satu solusi.

Algoritma Floyd Warshall juga membandingkan semua kemungkinan lintasan pada graf untuk setiap sisi dari semua simpul. Algoritma Floyd Warshall menerapkan pemrograman dinamis sehingga lebih menjamin keberhasilan penemuan solusi optimum untuk kasus penemuan lintasan terpendek (single pair shortest path).
Penerapan algoritma Floyd-Warshall dilakukan berdasarkan hasil yang diperoleh dari tahap analisa masalah. Algoritma Floyd-Warshall sangat efisien dari sudut pandang penyimpanan data karena dapat diimplementasikan dengan hanya pengubahan sebuah matriks jarak [4]. Adapun mekanisme dari algoritma FloydWarshall ini terdiri dari beberapa langkah yang harus dilakukan, yaitu :

a. Langkah awal yang harus dilakukan untuk menentukan shortest path dengan menggunakan algoritma Floyd-Warshall adalah dengan merepresentasikan suatu graf sebagai suatu matriks berbobot. Format output berupa matriks $\mathrm{n} \times \mathrm{n}$ berjarak $\mathrm{D}=[\mathrm{dij}]$ dimana dij merupakan jarak dari vertex i ke j.

b. Langkah kedua adalah melakukan dekomposisi Floyd-Warshall dengan urutan :

1. $\mathrm{d}_{\mathrm{ij}}{ }^{(\mathrm{k})}$ merupakan panjang dari shortest path dari i ke j, sehinggasemua vertex intermediate yang terdapat pada path (jika ada) terkumpul pada $\{1,2, \ldots ., \mathrm{k}\}$

2. $\mathrm{d}_{\mathrm{ij}}{ }^{(0)}$ dikumpulkan pada $\mathrm{w}_{\mathrm{ij}}$, yaitu tidak ada vertex intermediate.

3. $\mathrm{D}^{(\mathrm{k})}$ menjadi matriks $\mathrm{n} \mathrm{x} \mathrm{n}\left[\mathrm{d}_{\mathrm{ij}}{ }^{(\mathrm{k})}\right]$ Tentukan $\mathrm{d}_{\mathrm{ij}}{ }^{(\mathrm{n})}$ sebagai jarak dari i ke j kemudian hitung $\mathrm{D}^{(\mathrm{n})}$

4. Hitung $\mathrm{D}^{(\mathrm{k})}$ untuk $\mathrm{k}=0,1, \ldots, \mathrm{n}$

c. Langkah ketiga adalah menentukan struktur shortest path. Dalam hal ini, harus dilakukan dua pengamatan terlebih dahulu sebelum melangkah lebih jauh, yaitu :

1. Sebuah shortest path tidak memuat vertex yang sama sebanyak dua kali

2. Untuk sebuah shortest path dari $i$ ke $j$ dengan beberapa vertex intermediate pada path dipilih dari kumpulan $\{1,2, \ldots ., k\}$, dengan kemungkinan :

a. $k$ bukan merupakan vertex pada path 
Jurnal Pseudocode, Volume IV Nomor 2, September 2017, ISSN 2355-5920 www.ejournal.unib.ac.id/index.php/pseudocode

(path terpendek memiliki panjang $\mathrm{d}_{\mathrm{ij}}{ }^{\mathrm{k}-}$ 1)).

b. $\mathrm{k}$ merupakan vertex pada path (path terpendek memiliki panjang $\operatorname{dij}(\mathrm{k}-1)+$ $\operatorname{dij}(\mathrm{k}-1))$.

d. Setelah melakukan pengamatan diatas, kemudian dlakukan penentuan shortest path dari I k j yang memuat vertex $\mathrm{k}$ :

1. Shorter path tersebut Memuat sebuah path dari k ke j

2. Setiap subpath hanya dapat memuat pertex intermediate pada $(1, . ., k-1$.) dan sedapat mungkin memiliki nilai terpendek kemudian beri nama panjangnya $\operatorname{dik}(\mathrm{k}-1$ dan dkj(k-1) sehingga path memiliki panjang $(\operatorname{dik}(\mathrm{k}-1)+\mathrm{dkj}(\mathrm{k}-1)$.

e. Langkah-langkah adalah melakukan iterasi yang dimulai dari iterasi ke 0 sampai dengan. Perhitungan yang dilakukan adalah :

1. Menentukan $\mathrm{D}(0)$ (iterasi ke 0$)=[$ wij] merupakan matriks bobot.

2. Menentukan

$\mathrm{D}(\mathrm{k})$ dengan menggunakan rumus, $\operatorname{dij}(k)=\min \{\operatorname{dij}(k-1)$, $\operatorname{dik}(\mathrm{k}-1)+\operatorname{dkj}(\mathrm{k}-1)\}$, untuk $\mathrm{k}=1, \ldots, \mathrm{n}$ dimana $n$ adalah jumlah vertex.

Hasil akhir dari algoritma Floyd-Warshall adalah matriks untuk iterasi ke-n. Dari matriks ke$\mathrm{n}$ ini, dapat dilihat shortest path untuk setiap vertex padasuatu graph.

\section{E. Metode Graf}

Graf adalah kumpulan simpul (nodes) yang dihubungkan satu sarna lain melalui sisi/busur (edges) [5] Secara informal, suatu graf adalah himpunan benda- benda yang disebut verteks (atau node) yang terhubung oleh edge - edge. Biasanya graf digambarkan sebagai kumpulan titik - titik (melambangkan verteksi yang dihubungkan. oleh garis - garis (melambangkan edge - edge).

Graf $G$ didefinisikan sebagai pasangan himpunan $(V, E)$, yang dalam hal ini

: $V=$ himpunan berhingga dan tidak kosong dari simpul-simpul (vertices atau node) $=\left\{v_{1}, v_{2}, \ldots v_{n}\right.$ \} dan $E=$ himpunan sisi (edges atau $\operatorname{arcs}$ ) yang menghubungkan sepasang simpul $=\left\{e_{1}, e_{2}, \ldots\right.$ $e_{n}$ \}atau dapat ditulis singkat notasi $G=(V, E$.). Simpul pada graf dapat dinomori dengan huruf, seperti $v, w, \ldots$,dengan bilangan asli 1, 2, 3,..., atau gabungan keduanya. Sedangkan sisi yang menghubungkan simpul $V_{i}$ dengan simpul $V_{j}$ dinyatakan dengan pasangan $\left(v_{i}, v_{j}\right)$ atau dengan lambang $e_{1}, e_{2}$ menghubungkan simpul jika $e$ adalah sisi yang menghubungkan simpul $v_{i}$ dengan simpul $v_{j}$, maka e dapat ditulis sebagai :

$e=\left(v_{i}, v_{j}\right)$

Rumus :

$$
\mathrm{G}=(\mathrm{V}, \mathrm{E})
$$

Keterangan :

$\mathrm{G}=$ Pasangan himpunan $(V, E)$

$\mathrm{V}=$ Himpunan berhingga dan tidak kosong dari simpul-simpul (vertices atau node) $=\left\{v_{1}\right.$, $\left.v_{2, \ldots}, v_{n}\right\}$

$\mathrm{E}=$ Himpunan sisi (edges atau arcs) yang menghubungkan sepasang simpul $=\left\{e_{1}, e_{2}\right.$, $\left.\ldots e_{n}\right\}$

\section{F. Android}

Android adalah sistem operasi disematkan pada gadget, baik itu handphone, tablet, juga sekarang sudah merambah ke kamera digital dan jam tangan. Saat ini ganget bebasis Android, baik itu tablet atau handphone, begitu digandrungi. Selain harganya yang semakin terjangkau, juga juga varian spesipikasi yang bisa dipilih sesuai kebutuhan dan kantong [6].

Android merupakan suatu software stack yang 
Jurnal Pseudocode, Volume IV Nomor 2, September 2017, ISSN 2355-5920

www.ejournal.unib.ac.id/index.php/pseudocode

terdistribusi open source yang terdiri dari sistem operasi, middleware, dan key application (aplikasi dasar). Sistem operasi Android didisain untuk perangkat mobile dan merupakan turunan sistem operasi berbasis kernel linux, beberapa bagiannya juga indentik dengan sistem operasi GNU-Linux, diantaranya kernel, pustaka atau librari, framework, dengan penambahan Dalvik virtual machine dengan kata lain, OS Android saangan indentik dengan OS Linux. OS android tidak memilki sistem native X-Window seperti OS Linux dan tidak mendukung librari standar GNU seperti librari GNU C. Aplikasi yang berjalan pada OS GNU-Linux tidak akan dapat dijalankan pada perangkat Android.

\section{G. Google Maps}

Google Maps adalah layanan gratis yang diberikan oleh Google dan sangat popular.Google Maps adalah suatu peta dunia yang dapat kita gunakan untuk melihat suatu daerah. Dengan kata lain,Google Maps merupakan suatu peta yang dapat dilihat dengan menggunakan suatu browser. Kita dapat menambahkan fitur Google Maps dalam web yang telah kita buat atau pada blog kita yang berbayar maupun gratis sekalipun dengan Google Maps API. Google Maps API adalah suatu library yang berbentuk Java Script [7].

\section{H. Model Prototipe}

Model prototipe (prototyping model) dimulai dari mengumpulkan kebutuhan pelanggan terhadap perangkat lunak yang akan dibuat, lalu dibuat program protipe agar pelanggan lebih terbayang dengan apa yang sebenarnya diinginkan. Program prototype biasanya merupakan program yang belum jadi, program ini biasanya menyediakan tampilan dengan simulasi alur perangkat lunak yang sudah jadi. Program prototype ini dievaluasi oleh pelanggan atau user sampai ditemukan spesipikasi yang sesuai dengan keinginan pelanggan[8].

\section{METODE PENELITIAN}

\section{A. Tempat dan Waktu}

Penelitian akan dilakukan di Muara Aman Exspres, jalan Kalimantan No.7 RT. 04 RW. 03 Rawa Makmur Permai Bengkulu.

\section{B. Teknik Pengumpulan Data}

1. Metode Observasi

Metode observasi yaitu dengan melakukan pengamatan secara langsung dan mengambil datadata yang diperlukan untuk membuat sebuah tampilan aplikasi penentuan letak dan lokasi perusahaan travel/rental mobil di kota Bengkulu.

\section{Metode Studi Pustaka}

Data yang diperlukan untuk pengumpulan data yang diperoleh dengan cara melakukan studi pustaka, studi pustaka ini dilakukan dengan penelusuran ke perpustakaan, mempelajari bukubuku yang ada hubungannya dengan teori dan judul yang diangkat, dan pemanfaatan fasilitas internet dengan media search engine seperti google dan yahoo search.

\section{Desain Penelitian}

Pada penelitian ini dibuat suatu desain penelitian sebagai berikut: 


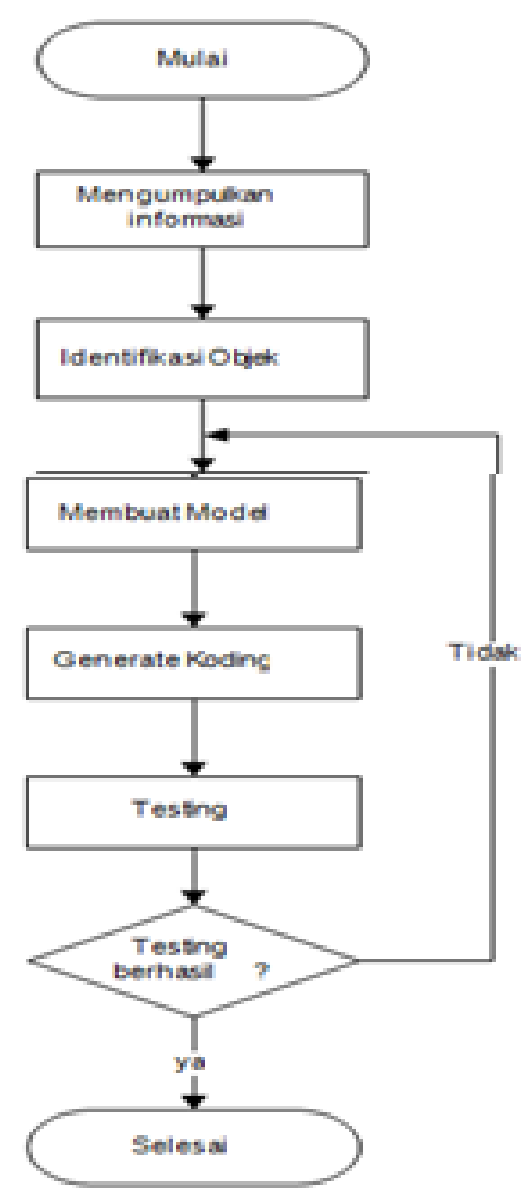

Gambar 1. Desain Penelitian

\section{Disain Flowchart Aplikasi}

Flowchart adalah penggambaran secara grafik dari langkah-langkah dan urut-urutan prosedur dari suatu program. Flowchart membantu programmer untuk memecahkan masalah kedalam segmensegmen yang lebih kecil dan menolong dalam menganalisis alternatif-alternatif lain dalam pengoperasian.

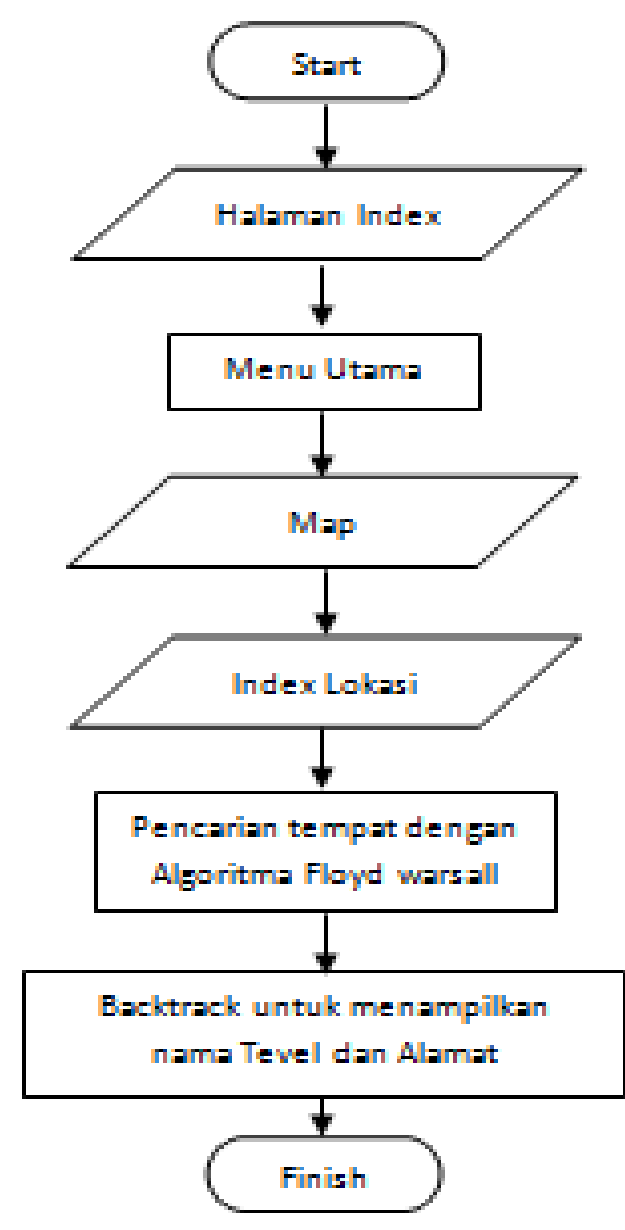

Gambar 2. Flowchart Aplikasi

\section{HASIL DAN PEMBAHASAN}

A. HASIL

\section{Tampilan Awal}

Tampilan awal merupakan tampilan yang pertama kali di lihat ketika user menjalankan aplikasi travel. Pada tampilan awal ini terdapat beberapa tombol yang bisa digunakan user, yaitu tombol letak GPS, marker dan tombol zoom. Tombol letak GPS digunakan untuk memfokuskan layar aplikasi menuju lokasi tempat user berada. Tombol marker merupakan tanda letak posisi kantor pemasaran tiket travel berada sedangkan tombol zoom digunakan untuk memperbesar dan mengecilkan ukuran map pada layar aplikasi. Untuk lebih jelasnya bisa dilihat pada gambar 3 di bawah ini: 
Jurnal Pseudocode, Volume IV Nomor 2, September 2017, ISSN 2355-5920 www.ejournal.unib.ac.id/index.php/pseudocode

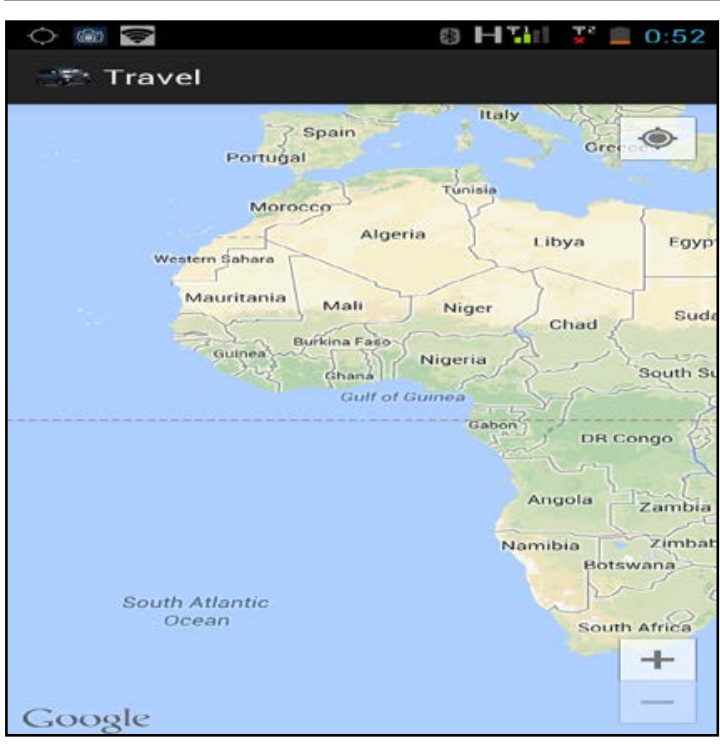

Gambar 3. Tampilan awal

Jika user mengklik tombol GPS maka akan tampil halaman seperti pada gambar di bawah ini :

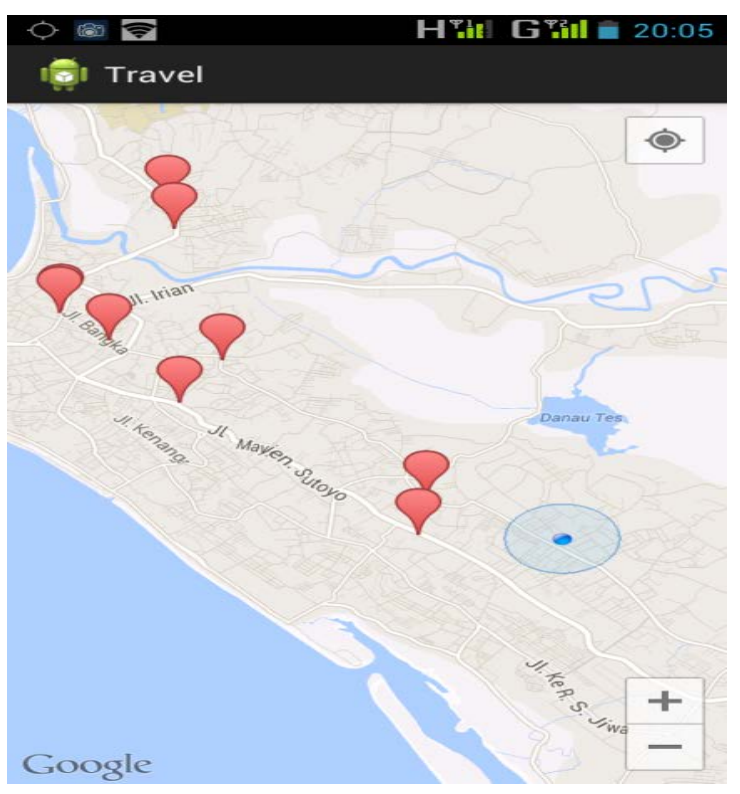

Gambar 4. Tampilan GPS User

Jika kita perhatikan gambar diatas, terdapat titik biru didalam lingkaran biru yang menandakan titik lokasi kita dalam peta. Marker dilambangkan dengan gambar seperti parasut warna merah. Titiktitik marker tersebut merupakan titik-titik lokasi travel dibengkulu yang mana datanya didapatkan sewaktu penelitian di Muara Aman Express Travel.
Data titik lokasi tersebut diambil dari database MySQL dan bantuan PHP untuk mengolah datanya. Data tersebut adalah sebagai berikut :

Tabel 1. Data dari Google Earth

\begin{tabular}{|c|c|c|c|c|}
\hline \multirow{2}{*}{ No } & \multirow{2}{*}{ Nama Travel } & \multirow{2}{*}{ Alamat } & \multicolumn{2}{|c|}{ Koordinat } \\
\hline & & & Latitude & Longitude \\
\hline 1 & $\begin{array}{l}\text { CV. Bengkulu Jaya } \\
\text { Travel }\end{array}$ & $\begin{array}{l}\text { Jl. Rawa Makmur No. } 6 \\
\text { Bengkulu } \\
\end{array}$ & -3.776 .350 & 102.274 .305 \\
\hline 2 & BHW Travel & Jalan Kampung Bali & -3.787 .924 & 102.264 .570 \\
\hline 3 & $\begin{array}{l}\text { CV.Anggi Wisata } \\
\text { Travel }\end{array}$ & $\begin{array}{l}\text { Jalan Jawa No. } 5 \text { RT } 10 \\
\text { Simpang } 3 \text { Sintiong }\end{array}$ & -3.788 .245 & 102.264 .416 \\
\hline 4 & $\begin{array}{l}\text { Gama Mandiri } \\
\text { Travel }\end{array}$ & \begin{tabular}{|l} 
Jalan Bangka No. 8 Pasar \\
Minggu \\
\end{tabular} & -3.792 .183 & 102.268 .649 \\
\hline 5 & CV. Amin Travel & Jalan Dempo 7 Sawah Lebar & -3.795 .029 & 102.278 .346 \\
\hline 6 & $\begin{array}{l}\text { CV.PO. Top } \\
\text { Travel dan Express }\end{array}$ & $\begin{array}{l}\text { Jalan S. Parman. No. } 58 \\
\text { Padang Jati } \\
\end{array}$ & -3.801 .109 & 102.274 .744 \\
\hline 7 & $\begin{array}{l}\text { Bengkulu Citra } \\
\text { Nauli }\end{array}$ & \begin{tabular}{|l|} 
Jalan Semangka Raya \\
Panorama \\
\end{tabular} & -3.814 .612 & 102.295 .873 \\
\hline 8 & $\begin{array}{l}\text { CV. Trans Wisata } \\
\text { Travel }\end{array}$ & Jalan P. Natadirja. KM. 6, 5 & -3.819 .875 & 102.295 .230 \\
\hline 9 & $\begin{array}{l}\text { Muara Aman } \\
\text { Express }\end{array}$ & $\begin{array}{l}\text { Jalan Kalimantan Rawa } \\
\text { Makmur }\end{array}$ & -3.772 .395 & 102.273 .659 \\
\hline
\end{tabular}

Untuk mendapatkan koordinat lokasi diatas, penulis menggunakan bantuan dari aplikasi Google Earth. Untuk mendapatkan koordinat seperti diatas, penulis mengubah opsi pilihan perlihatkan Lin/Buj di menu perangkat-pilihan. Untuk lebih jelasnya dapat dilihat seperti gambar dibawah ini :

\begin{tabular}{|c|c|c|c|}
\hline \multicolumn{2}{|l|}{ POosi Google :ath } & \multicolumn{2}{|r|}{$9 x$} \\
\hline \multicolumn{4}{|c|}{ 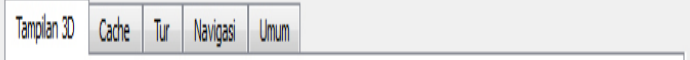 } \\
\hline Wama Testur & 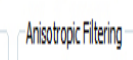 & 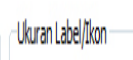 & Notevolis \\
\hline O High codor(160t) & Ollondiff & O Keed & O opera. \\
\hline $0 \operatorname{Trec} \cos (32 b i t)$ & 0 Setarng & OS Selding & Odiedt \\
\hline ఫ1 Kanpesilan & O Ting & O besar & Tanklan node anden \\
\hline 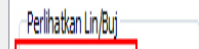 & Sthonlluvan & font- & \\
\hline Q Derijittesinal & 0 Defaltistem & & \\
\hline 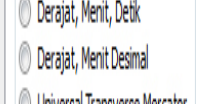 & 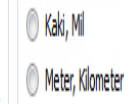 & Pithentid & \\
\hline 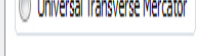 & & & \\
\hline
\end{tabular}

Gambar 5. Tampilan Setting Perlihatkan Lintang/Bujur

Setelah opsi tampilan Lin/Buj diubah ke decimal, maka langkah selanjutnya adalah mencari titik-titik lokasi travel yang ada di 
Jurnal Pseudocode, Volume IV Nomor 2, September 2017, ISSN 2355-5920 www.ejournal.unib.ac.id/index.php/pseudocode

Bengkulu. Setelah titik lokasi ketemu maka kita tinggal tambahkan tanda letak ke lokasi yang ingin dicari koordinatnya. Untuk lebih jelasnya bisa dilihat

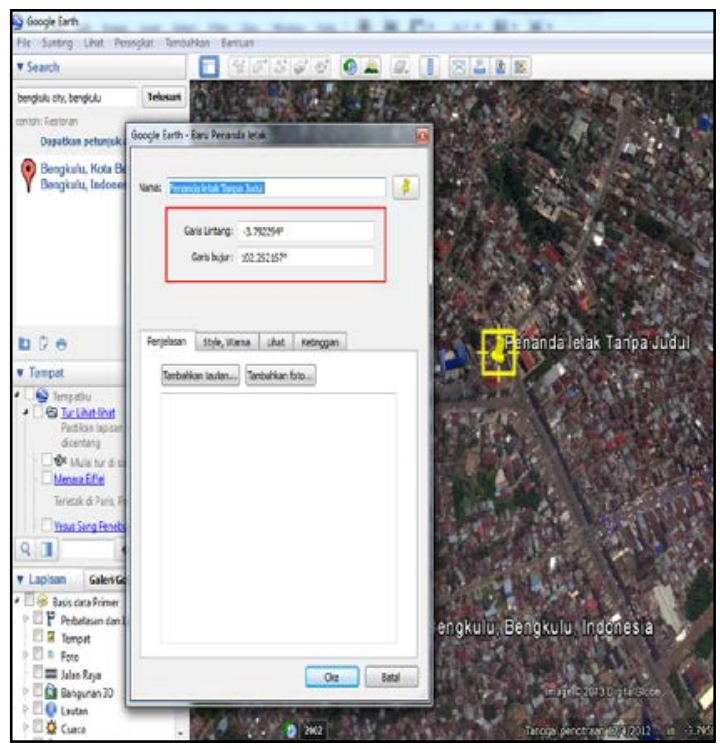

Gambar 6. Tampilan Koordinat Lokasi

\section{Tampilan Info Marker}

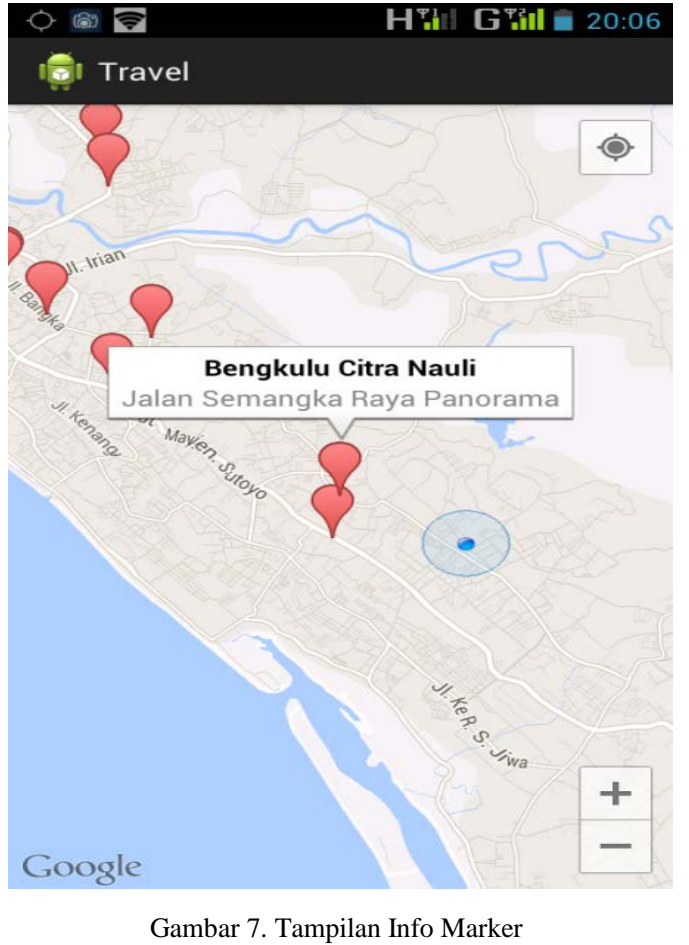

3. Tampilan Info Windows

Tampilan info windows akan aktif jika user mengklik info marker seperti yang ada pada
Gambar 7 di atas. Pada tampilan info windows terdapat bebera text views seperti nama travel, alamat travel dan nomor hp yang bisa dihubungi. Selain itu terdapat juga tombol Tampilkan jalur untuk mengaktifkan class direction.java sehingga tampil jalur terdekat menuju lokasi travel tersebut. Tampilan Info Windows selengkapnya dapat terlihat pada gambar 8 dibawah ini:

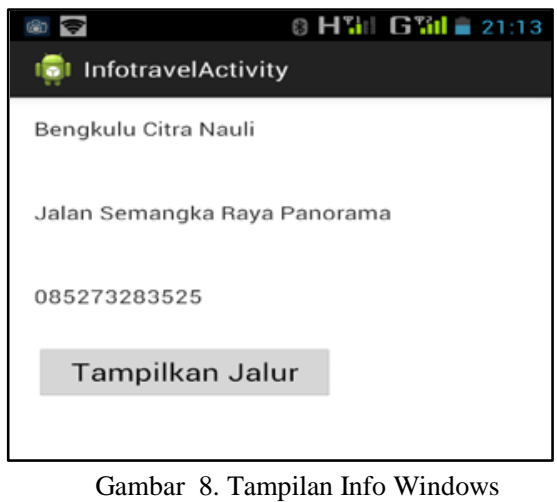

4. Tampilan Jalur

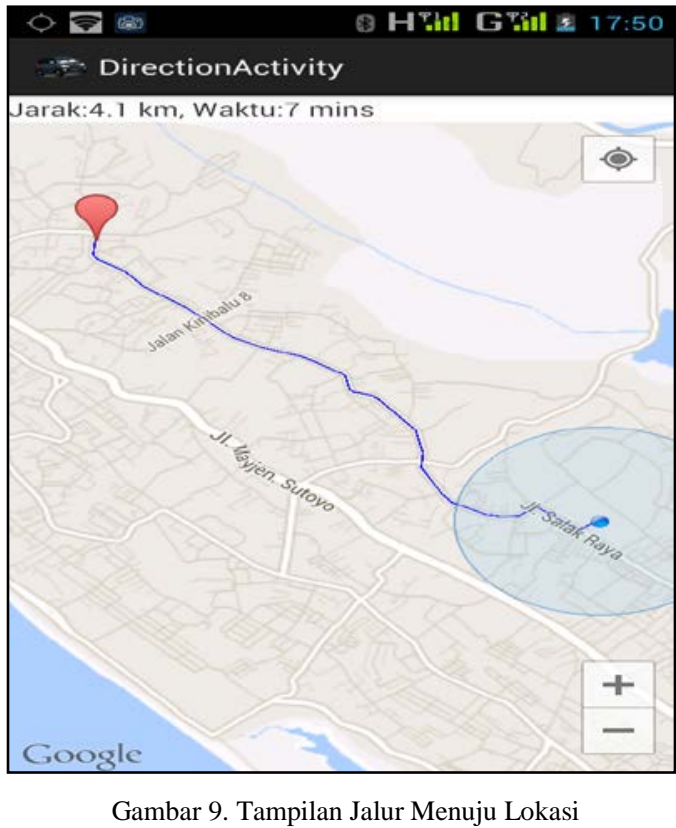

Seperti yang terlihat pada gambar diatas, pada halaman ini ditampilkan jalur terdekat menuju lokasi travel yang user ingin datangi. Tampilan ini akan aktif jika user mengklik tombol tampilkan jalur pada tampilan info windows. Untuk menampilkan jalur terdekat. 
Jurnal Pseudocode, Volume IV Nomor 2, September 2017, ISSN 2355-5920 www.ejournal.unib.ac.id/index.php/pseudocode

\section{B. Pembahasan}

1. Estimasi Terhadap Jarak dan Waktu

Perhitungan algoritma Floyd ambil sample menghitung jalur dari terminal panorama menuju simpang lima suprapto.

Tabel 2. Nilai Bobot

\begin{tabular}{|c|c|c|c|}
\hline \multirow[t]{2}{*}{ Simpul } & \multirow[t]{2}{*}{ Link ke Simpul } & Bobot & $\begin{array}{l}\text { Bobot } \\
\text { Waktu }\end{array}$ \\
\hline & & Jarak & Normal \\
\hline \multirow[t]{2}{*}{ NA(Terminal) } & $\begin{array}{l}\text { N1 (Simpang } \\
\text { Panorama) }\end{array}$ & $750 \mathrm{~m}$ & 1 menit \\
\hline & N2 (Balai Buntar) & $750 \mathrm{~m}$ & 1 menit \\
\hline \multirow{2}{*}{ N1 (simpang panorama) } & $\begin{array}{l}\text { N3 (simpang padang } \\
\text { harapan) }\end{array}$ & $750 \mathrm{~m}$ & 1 menit \\
\hline & N8 (BLK) & $600 \mathrm{~m}$ & $50 \mathrm{sec}$ \\
\hline N2 (Balai Buntar) & N7 (KM 6,5) & $500 \mathrm{~m}$ & $26 \mathrm{sec}$ \\
\hline $\begin{array}{l}\text { N3 (simpang padang } \\
\text { harapan) }\end{array}$ & N4 (Tanah Patah) & $1100 \mathrm{~m}$ & 1 menit \\
\hline N4 (Tanah Patah) & N5 (Skip) & $1600 \mathrm{~m}$ & 2menit \\
\hline N5 (Skip) & N6 (Simpang Lima) & $800 \mathrm{~m}$ & $41 \mathrm{sec}$ \\
\hline N7 (KM 6,5) & N3 (simpang padang & $750 \mathrm{~m}$ & $56 \mathrm{sec}$ \\
\hline N8 (BLK) & N9 (Tebeng) & $1200 \mathrm{~m}$ & 2 menit \\
\hline N9 (Tebeng) & N10 (Sawah Lebar) & $1500 \mathrm{~m}$ & 2menit \\
\hline \multirow{2}{*}{ N10 (Sawah Lebar) } & N11 (Simpang Jam) & $450 \mathrm{~m}$ & $48 \mathrm{sec}$ \\
\hline & N5 (Skip) & $650 \mathrm{~m}$ & $54 \mathrm{sec}$ \\
\hline N11 (Simpang Jam) & N6 (Simpang Lima) & $600 \mathrm{~m}$ & $34 \mathrm{sec}$ \\
\hline
\end{tabular}

(Sumberdata: googlemaps)

Berikut adalah langkah-langkah dalam menyeleseikan masalah rute dengan jalur Terminal Panorama menuju Simpang Lima Suprapto yang terdapat padaTabel 2 . dengan menggunakan algoritma Floyd Warshall untuk mencari rute terpendek.

Pada langkah pertama, ada 2 simpul yang bisa dilalui dari simpul awal NA, yaitu N1dan N2. Pada saat menemui persimpangan algoritma Floyd Warshall akan mencoba satu persatu dari kemungkinan yang ada. Pada langkah ke-2, setelah mengambil simpul N1, maka kemudian algoritma akan memeriksa, ada berapa kemungkinan jalur yang bisa dilalui dari N1. Ternyata jalur yang terhubung dengan simpul N1ada N3 dan N8. Sedangkan yang terhubung dengan N2 hanya N7 sehingga N7 terpilih menjadi jalur satu-satunya. Setelah itu dilakukan lagi pengecekan seperti sebelumnya sampai ke tempat tujuan.
Dari pengecekan tersebut didapatkan jalur sebagai berikut :

a. Jalur Pertama

Tabel 3. Jalur Pertama

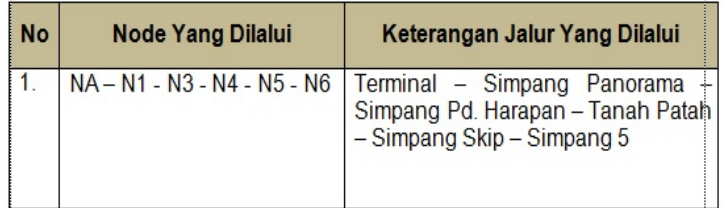

Berikut perhitungan Total jarak dan waktu tempuh:

$$
\begin{aligned}
\text { Jarak }= & \text { NA }-\mathrm{N} 1-\mathrm{N} 3-\mathrm{N} 4-\mathrm{N} 5-\mathrm{N} 6 \\
= & 750+750+1100+1600+800 \\
& =5000 \mathrm{~m}=5 \mathrm{~km} \\
\text { Waktu }= & 60+60+60+120+41 \\
= & 341 \mathrm{sec}=5,6 \text { menit }
\end{aligned}
$$

b. Jalur Kedua

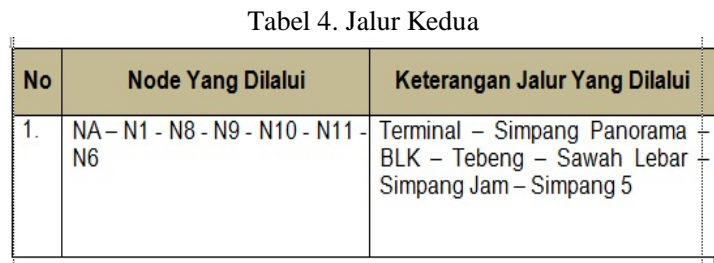

Jarak = NA - N1 - N8 - N9 - N10 - N11-

N6

$=750+600+1200+1500+450+$

600

$=5100 \mathrm{~m}=5,1 \mathrm{~km}$

Waktu $=60+50+120+120+48+34$

$=432 \mathrm{sec}=7,2$ menit

c. Jalur Ketiga

Tabel 5. Jalur Ketiga

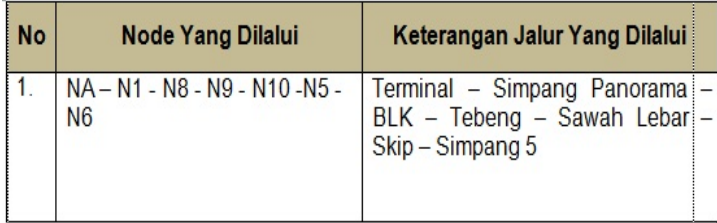

Jarak $=\mathrm{NA}-\mathrm{N} 1-\mathrm{N} 8-\mathrm{N} 9-\mathrm{N} 10-\mathrm{N} 5-$

N6

$=750+600+1200+1500+650+$

800

$=5500 \mathrm{~m}=5,5 \mathrm{~km}$ 
Jurnal Pseudocode, Volume IV Nomor 2, September 2017, ISSN 2355-5920 www.ejournal.unib.ac.id/index.php/pseudocode

Waktu $=60+50+120+120+54+41$

$=445 \mathrm{sec}=7,4$ menit

d. Jalur Keempat

Tabel 6. Jalur Keempat

\begin{tabular}{|l|l|l|}
\hline No & \multicolumn{1}{|c|}{ Node Yang Dilalui } & \multicolumn{1}{|c|}{ Keterangan Jalur Yang Dilalui } \\
\hline 1. & $\begin{array}{l}\text { NA- N2 - N7 -N3 - N4 - N5 - } \\
\text { N6 }\end{array}$ & $\begin{array}{l}\text { Terminal - Balai Buntar - KM 6,5 - } \\
\text { Simpang Pd. Harapan - Tanah Patah } \\
\text { - Simpang Skip - Simpang 5 }\end{array}$ \\
\hline
\end{tabular}

Jarak $=\mathrm{NA}-\mathrm{N} 2-\mathrm{N} 7-\mathrm{N} 3-\mathrm{N} 4-\mathrm{N} 5-\mathrm{N} 6$

$=750+500+750+1100+1600+$

800

$=5500 \mathrm{~m}=5,5 \mathrm{~km}$

Waktu $=60+26+56+60+120+41$

$=363 \mathrm{sec}=6,05$ menit

Setelah total jarak dan waktu dari keempat jalur diketahui maka selanjutnya total jarak akan disimpan.

Tabel 7. Total Jarak dan Waktu

\begin{tabular}{|l|r|r|}
\hline \multicolumn{1}{|c|}{ JALUR } & $\begin{array}{c}\text { TOTAL } \\
\text { JARAK TEMPUH }\end{array}$ & $\begin{array}{c}\text { TOTAL } \\
\text { WAKTU TEMPUH }\end{array}$ \\
\hline & $5 \mathrm{Km}$ & $5,6 \mathrm{Menit}$ \\
\hline Jalur Kedua & $5,1 \mathrm{Km}$ & 7,2 Menit \\
\hline Jalur Ketiga & $5,5 \mathrm{Km}$ & 7,4 Menit \\
\hline Jalur Keempat & $5,5 \mathrm{Km}$ & 6,05 Menit \\
\hline
\end{tabular}

Dari tabel diatas, diketahui bahwa jalur terdekat yaitu jalur pertama yaitu terminal panorama simpang panorama - simpang padang harapan tanah patah - simpang skip - simpang 5 dengan jarak $5 \mathrm{~km}$ dan waktu tempuh 5,6 menit.

\section{Hasil Pengujian Black Box}

Metode pengujian black box untuk menguji aplikasi yang telah dibuat dalam segi tampilan user interface.
Tabel 8. Pengujian Menggunakan Black Box

\begin{tabular}{|l|l|l|l|c|}
\hline No & Requirement & $\begin{array}{l}\text { Skrenario } \\
\text { Uji }\end{array}$ & Hasil Yang Diharapkan & $\begin{array}{c}\text { Hasil } \\
\text { Pengujian }\end{array}$ \\
\hline 1 & Map & $\begin{array}{l}\text { Tampilan } \\
\text { Map }\end{array}$ & Aplikasi Menampilkan Map & sesuai \\
\hline \multirow{2}{*}{2} & \multirow{2}{*}{ GPS } & $\begin{array}{l}\text { Tombol } \\
\text { Gps }\end{array}$ & $\begin{array}{l}\text { aplikasi mengarahkan } \\
\text { map ke lokasi user }\end{array}$ & sesuai \\
\cline { 3 - 5 } & Titik GPS & $\begin{array}{l}\text { aplikasi menampilkan titik } \\
\text { lokasi user }\end{array}$ & sesuai \\
\hline \multirow{2}{*}{3} & \multirow{2}{*}{ marker } & $\begin{array}{l}\text { Tampilan } \\
\text { Marker }\end{array}$ & $\begin{array}{l}\text { Aplikasi Menampilkan } \\
\text { Merker Pada Titik Lokasi }\end{array}$ & sesuai \\
\cline { 3 - 5 } & $\begin{array}{l}\text { Tampilan } \\
\text { Marker } \\
\text { Jika Diklik }\end{array}$ & $\begin{array}{l}\text { Ada Tampilan Informasi } \\
\text { Nama Pada Marker Ketika } \\
\text { Di Klik }\end{array}$ & sesuai \\
\hline \multirow{2}{*}{4} & $\begin{array}{l}\text { Halaman } \\
\text { Informasi } \\
\text { Marker }\end{array}$ & $\begin{array}{l}\text { User } \\
\text { Mengklik } \\
\text { Marker 2 } \\
\text { Kali }\end{array}$ & $\begin{array}{l}\text { Aplikasi Menampilkan } \\
\text { Halaman Informasi Marker } \\
\text { Jika Diklik2 Kali }\end{array}$ & sesuai \\
\hline \multirow{2}{*}{5} & \multirow{2}{*}{ Jalur } & $\begin{array}{l}\text { User Klik } \\
\text { Tampilkan } \\
\text { Jalur }\end{array}$ & $\begin{array}{l}\text { Aplikasi Menampilkan } \\
\text { Jalur Terdekat }\end{array}$ & sesuai \\
\hline
\end{tabular}

\section{KESIMPULAN DAN SARAN}

\section{A. Kesimpulan}

Berdasarkan dari hasil uji coba dapat diambil kesimpulan sebagai berikut:

1. Untuk mencapai rute dengan jalur Terminal Panorama menuju Simpang Lima Suprapto, dengan jalur, maka pada jalur pertama dengan jarak $5 \mathrm{~km}$ dapat ditempuh dalam waktu 5,6 menit, jalur kedua dengan jarak 5,1 km dapat ditempuh dalam waktu 7,2 menit, jalur ketiga dengan jarak 5,5 km dapat ditempuh dalam waktu 7,4 menit dan jalur keempat dengan jarak 5,5 km dapat ditempuh dalam waktu 6,05 menit.

2. Jalur terdekat yaitu jalur pertama yaitu terminal panorama - simpang panorama simpang padang harapan - tanah patah simpang skip - simpang 5 dengan jarak 5km dan waktu tempuh 5,6 menit.

3. Permasalahan atau hambatan dimana suatu tujuan sulit untuk dicapai karena berhubungan dengan situasi, kondisi yang di luar perkiraan di lapangan. 
B. Saran

Dalam implementasi algoritma floyd warshall untuk wenentukan letak dan lokasi Perusahaan travel/rental mobil di kota Bengkulu banyak memiliki kekurangan, maka dari itu perlu adanya pengembangan dan kontribusi positif untuk menyempurnakannya. Penulis berharap ada pihak yang mengembangkan aplikasi ini, diharapkan apabila ada perubahan baik itu penambahan, pengurangan dan modifikasi lainnya yang berhubungan dengan lokasi dan informasi yang bersangkutan di tahun berikutnya dapat diadakan pembaharuan (upgrade) untuk aplikasi Implementasi Algoritma Floyd Warshall Untuk Menentukan Letak dan Lokasi Perusahaan Travel/Rental Mobil di kota Bengkulu untuk versi selanjutnya.

\section{REFERENSI}

[1] Riyanto, dkk. 2009. Pengembangan Aplikasi Sistem Informasi Geografis Berbasis Dekstop dan Web. Yogyakarta: Penerbit Gava Media.

[2] Parkinson, 1996, Global Positioning System: Theory and Applications, American Institute of Aeronautics and Astronautics, Washington D.C.

[3] MustikaGunitaDkk, 2013. AplikasiPenandaLokasiPeta Digital BerbasisGIS PadaSmartphone Android :Volume 2, Nomor 4, Tahun 2013, (ISSN : 2337-845X).

[4] Budiarsyah, Dibi Khairurrazi . 2010. Algoritma Djikstra, Bellman-Ford, Dan Floyd-Warshall Untuk Mencari Rute Terpendek Dari Suatu Graf. Makalah Strukdis 2010 , Bandung.

[5] Siang,Jong Jek. (2002). Matematika Diskrit dan Aplikasinya Pada Ilmu Komputer, Yogyakarta: Andi Yogyakarta

[6] Wahadyo, Agus,. 2013. Android 4 UntukPenggunaPemula Tablet danHandphone : Jakarta : Media kita.

[7] Kindarto, Asdani. 2008. Asyik Berinternet dengan Beragam Layanan Google. Yogyakarta:Penerbit Andi.

[8] [A.S. Rosa, Salahuddin. 2013. Rekayasa Perangkat Lunak Terstruktur dan Berorientasi Objek: Bandung :Informatika. 
Jurnal Pseudocode, Volume IV Nomor 2, September 2017, ISSN 2355-5920 www.ejournal.unib.ac.id/index.php/pseudocode 